\title{
The effect of AC and MFDC resistance spot welding technology on mechanical properties of new generation automotive steels
}

\section{AC ve MFDC nokta direnç kaynak teknolojilerinin yeni nesil otomotiv çeliklerinin mekanik özelliklerine etkisi}

\author{
Mehtap HIDIROGLU1* iD , Unal KAHRAMAN² iD , Nizamettin KAHRAMAN ${ }^{3}$ iD \\ ${ }^{1}$ Coşkunöz Holding Inc., Bursa, Turkey. \\ mhidiroglu@coskunoz.com.tr \\ 2Unis Machine Industry and Trade Ltd. Co., Bursa, Turkey. \\ ukahraman@unismakina.com \\ ${ }^{3}$ Manufacturing Engineering, Technology Faculty, Karabuk University, Karabük, Turkey.
} nkahraman@karabuk.edu.tr

\section{Abstract}

Usage of UHSS (ultra high-strength steels) had increased in recent years, automobile Body in White-BIW- manufacturers had faced the challenge of choosing between two types of currents for resistance spot welding equipment. The objective of this work is to compare the effects of welds obtained from both AC and MFDC (alternate current-AC-power source and medium frequency constant current one-MFDC) machines on mechanical performance. Two different welding equipment had been used for making joints between as-delivered 22MnB5 and DP600 steel sheets. The micro-hardness results, tensile shear (TS) and cross tension (CT) tests of resistance spot welded (RSW) joints between as - delivered (22MnB5) and double phase (DP600) steels for both AC and MFDC process are detailed. According to the results, comparatively lower hardness values were observed in the weld metal and heat effected zones of the welded samples obtained by MFDC technology compared to $A C$ technology. The positive effect was observed in the strength and elongation values of the samples welded with MFDC technology according to AC technology. When the CT and TS test results were evaluated, more than 5\% improvement is observed on welded samples with MFDC technology. The originality of this paper presents a comparative study of joint performance properties effect for both $A C$ and MFDC process on dissimilar joints between as-delivered 22MnB5 and DP600.

Keywords: Resistance spot welding, As delivered 22MnB5, DP600, $\mathrm{AC}$ and MFDC resistance spot welding.

\section{Introduction}

Dual-phase (DP) steels and hot stamped martensitic steels, have important impacts for sustainable manufacturing of vehicles. Besides the pure technical benefits coming from these steels have cost advantages by weight reduction for automotive industry.

$22 \mathrm{MnB} 5$ continues to be preferred with increasing acceleration in the automotive industry due to some advantages of tensile strength up to $1500 \mathrm{MPa}$, as well as lightness, reduction in fuel consumption, crash resistance and high formability [1]-[4]. In order to increase its hardenability, 22MnB5 steel with low amount of boron and high amount of magnesium elements added to its chemical structure are in the class of Ultra high
Öz

Özellikle ultra yüksek mukavemetli çeliklerin kullanımı son yıllarda arttıkça, araç gövdesi, üreticileri nokta direnç kaynak ekipmanı için iki akım türü arasında seçim yapma zorluğu ile karșı karșıya kalmıștır. Bu çalışmanın amacl, alternatif akım (AA) ve orta frekans doğru akım (OFDA) güç kaynak makinelerinden elde edilen kaynaklı bağlantıların mekanik performans üzerindeki etkilerini karșılaștırmaktır. Preslenmemiş 22MnB5 ve DP600 çelik saclar arasındaki bağlantı için iki farklı kaynak ekipmanı AA ve OFDA teknolojisi kullanılmıștır. Hem AC hem de OFDA işlemi için preslenmemiş (22MnB5) ve çift fazlı (DP600) çelik arasındaki nokta direnç kaynaklı bağlantıların mikro sertlik sonuçları, çekme makası ve çapraz gerilim testleri ayrıntılı olarak açıklanmaktadır. Sonuçlara göre, OFDA teknolojisi ile elde edilen kaynakl örneklerin kaynak metali ve ITAB bölgelerinde AA teknolojisine klyasla nispeten daha düşük sertlik değerleri gözlenmiştir. AA teknolojisine göre OFDA teknolojisi ile kaynak yapılmıș numunelerin mukavemet ve uzama değerlerinde pozitif etki gözlenmiştir. Çapraz çekme ve çekme makaslama testi sonuçları değerlendirildiğinde, OFDA teknolojisine sahip kaynakl numunelerde \%5'ten fazla iyileşme gözlenmektedir. Bu makalenin özgünlüğü hem AA hem de OFDA prosesinin preslenmemiș $22 \mathrm{MnB5}$ ve DP600 arasindaki farkli bağlantının performans özelliklerine etkisini inceleyen karşılaştırmalı bir çalıșma sunmaktır.

Anahtar kelimeler: Nokta direnç kaynağı, Preslenmemiș 22MnB5, DP600, AA ve OFDA nokta direnç kaynağı.

strength steels [5]. The reason why $22 \mathrm{MnB5}$ is preferred in Anti-collision BIW parts (A pillar, B pillar, side/roof rails) is that it has a completely martensite structure after hot forming (HF) operation and exhibits tensile strength over $1500 \mathrm{MPa}$ [6],[7] (Figure 1).

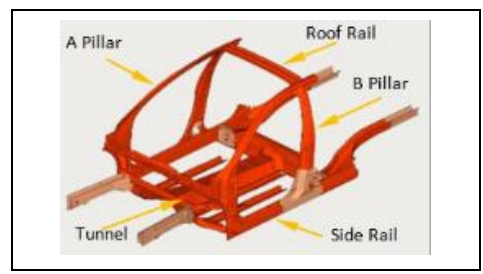

Figure 1. Overview of BIW (Body in White) parts used hot stamped boron steel.

${ }^{*}$ Corresponding author/Yazışılan Yazar 
UHSS steels are had low formability properties with undesired high springback at room temperature. Therefore, when we look globally, the locations and numbers of alternative HS processes are increasing day by day. The reason for this increase is BIW parts with complicated geometry can be forming with low springback without deformation. In the HF operation of BIW parts, the sheets are pressed and quenched on Ac3 at high temperature immediately after the structure turns completely into austenite. Thus, almost completely martensite converted microstructure, which provides the highest strength value, is obtained at the end of the process [8]. Before the HF process hot formable boron steel with a tensile strength of $600 \mathrm{MPa}$ increases strength to approximately $1500 \mathrm{MPa}$ after the HF process [5]. In the direct HS process, the steel is heated at austenitization temperature between $900-950$ degrees for 5 or $10 \mathrm{~min}$. followed by quenching at a cooling rate of $30-50 \mathrm{~K} / \mathrm{s}$. The high cooling rate causes the austenite structure to turn into martensite and thus gain high strength [1],[2],[4]. During the HS process, it is necessary to watch out the step of transferring the part from the furnace to the forming mold. Because the contact of the steel surface with the atmosphere leads to oxidation and decarburization [3],[9]. Patented aluminum silicon (Al-Si) coating technology is widely used in order to protect these grade steels from the negative effects of the atmosphere [3],[10]. DP steels obtained by the dispersion of the hard martensite phase in the ductile and soft ferrite matrix are used in BIW safety cage designs by combining with HF steels. The most important factor affecting the mechanical properties of DP steel classes is the balance of the volume fractions established between the martensite phase dispersed in the ferrite matrix [11],[12]. After the HF process, the pressed BIW parts are assembled together by suitable joining methods. In some BIW applications, boron alloy martensitic steels can be hot formed after welding with double phase steels. Various welding methods (RSW, Laser, MAG welding) are used in the assembly of BIW parts. While determining the method and welding process parameters, the effect of hardness distribution maps on welding area, cracking sensitivity and softening in the heat affected area (HAZ) should be examined.

BIW assemblies use lots of weldment joints to transfer crash loads through the BIW structure during crash. The joint failure occurs on the RSW welded BIW parts during crash is important failure type [13]. The process window for RSW of hot stamping steel is generally narrower compared to conventional automotive steels [14]. According to the claim of Park et al., In UHSS class hard steels the welding currents used in a high and narrow range are the reason for expulsion, and the weldment zone between the acceptance limits is narrow [15]. Coatings used to prevent oxidation during the HS process can be among the causes of this condition [14]. Another reason affects weldability is elements added for alloying. These elements added to the chemical composition increase the resistance and accelerate the formation of heat during the welding process. This reduces weldability and causes expulsion. Lee et al. [16] investigated the effects of boron ratio in the chemical composition of HF steels on weldability. The results showed increasing boron amount can increase crack formation. The high hardenability properties of HF steels show that the welded zone is prone to notch sensitivity and consequently of this interface failures can occur [17].

Choi et al. [18], had been investigated the effect of the weld current on the nugget diameter, load-carrying capacity and fracture behavior of the weld between $22 \mathrm{MnB5}$ and GA780DP steel sheets. Ductile regions had been observed on the interfacialy fractured surface of weld. It is stated that the microstructure is fragile due to its high carbon equivalent and Al's penetration into the weld. It is also stated fracture was caused by the high hardness of the weld and the fragile microstructure, as well as the concentration of stress from the boundary of the nugget. Aras et all [19] had been investigated mechanical properties of RSW welded DP800, as-received Usibor1500 and Ductibor 500P three advised high strength steel with different thickness. According to the result they reached, when different types of steels are welded together, the maximum tensile-shear force and elongation achieved are higher than those of same type of materials. Tuncel and Aydın [20], had been experimentally investigated the effect of weld time and weld current on the tensile properties of RSW welded Usibor 1500 steel sheets with a thickness of $2 \mathrm{~mm}$. Derived major conclusion from their investigation, tensile shear load and elongation values had been increased with increasing weld current. Sejč and Belanová [21], had been investigated and evaluated the influence of welding parameters of steel studs on USIBOR 22MnB5 steel sheet with AlSi coating on selected mechanical properties of joints. They had been found a significant hardness value difference between the subcritical heat affected zone from the USIBOR 22MnB5 plate and the steel stud and the inter-critical HAZ on both sides of the welded materials.

Failure mode types can significantly affect energy and load carrying capacity in resistance spot welding. Generally, the pull out failure mode is the preferred fracture type due to its higher associated plastic deformation and its ability to absorb energy al [22],[23]. Vehicle crash resistance can be significantly reduced when interfacial failure occurs at spot welding [24]. Pull out failure mode during quality control indicates that the weld can transmit a high level of force, causing heavy plastic deformation in adjacent components and increasing strain energy distribution in impact conditions [25]. Therefore, welding parameters need to be adjusted and well considered in automobile design by automotive industry to achieve pull out failure.

Studies in the literature have mostly concentrated on the effect of different sheet thickness and parameters of the resistance spot welding on the mechanical properties of new generation steels [13],[22]. The effects of AC and MFDC resistance spot welding method on the mechanical properties of advanced high strength automotive steels joints are presented in this work. Mechanical properties of as-delivered 22MnB5 and DP600 sheet pairs which ae welded these RSW methods were tested and the effects of different RSW technologies on the strength and performance of the joints were compared.

\section{Test materials}

RSW experiments were performed between joints of as $1.5 \mathrm{~mm}$ thick as-received $22 \mathrm{MnB} 5$ steel sheet ( $45 \mu \mathrm{m} \mathrm{Al}$-Si coated) and $1.6 \mathrm{~mm}$ thick galvanized DP600 steel sheet ( $5 \mu \mathrm{m}$ Zn coated). The chemical composition of the materials is given in Table 1 . Cutting process was achieved by using laser cutting method. $100 \mathrm{~mm}$ long and $30 \mathrm{~mm}$ wide samples were prepared according to EN ISO 14273 standards. Microstructure photographs and tensile test results of the base materials were taken in preliminary works stage the study. The microstructure of the main materials can be seen in Figure 2. The results of base metals tensile strength and images subjected to the tensile strength test can be seen respectively in Figure 3 and Figure 4. 
Table 1. Chemical composition of 22MnB5 and DP600 (max. \% atomic weight).

\begin{tabular}{cccccccccccccc}
\hline Material & $\mathrm{C}$ & $\mathrm{Si}$ & $\mathrm{Mn}$ & $\mathrm{P}$ & $\mathrm{S}$ & $\mathrm{Al}$ & $\mathrm{B}$ & $\mathrm{Ti}+\mathrm{Nb}$ & $\mathrm{Cr}+\mathrm{Mo}$ & $\mathrm{Fe}$ \\
\hline DP600 & 0.1 & 0.5 & 1.9 & 0.03 & 0.03 & $0.015-0.2$ & 0.001 & 0.24 & - & Rest \\
22MnB5 & 0.25 & 0.4 & 1.4 & 0.03 & 0.01 & $0.01-0.1$ & 0.005 & 0.12 & 1 & Rest \\
\hline
\end{tabular}

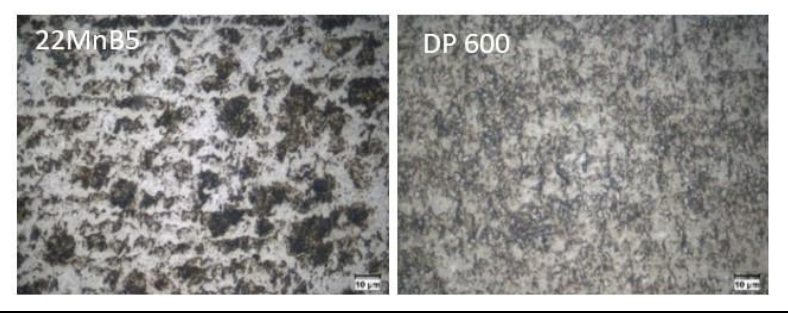

Figure 2. Base metals microstructures: As received 22MnB5 (before any heat treatment and stamping), and DP600.

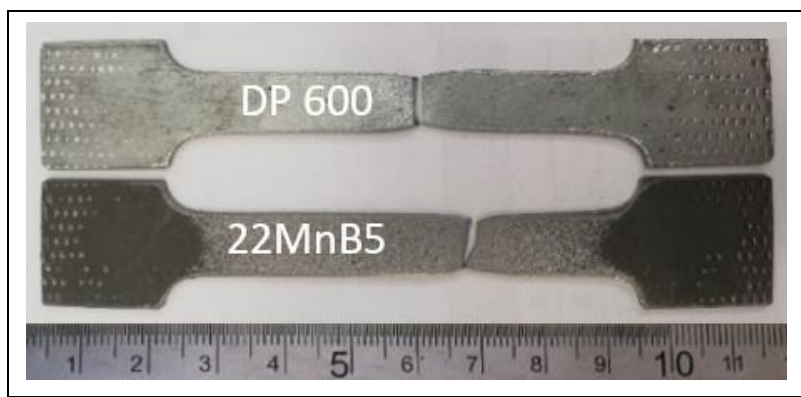

Figure 3. Base metals tensile strength sample images: As received 22MnB5, and DP600.

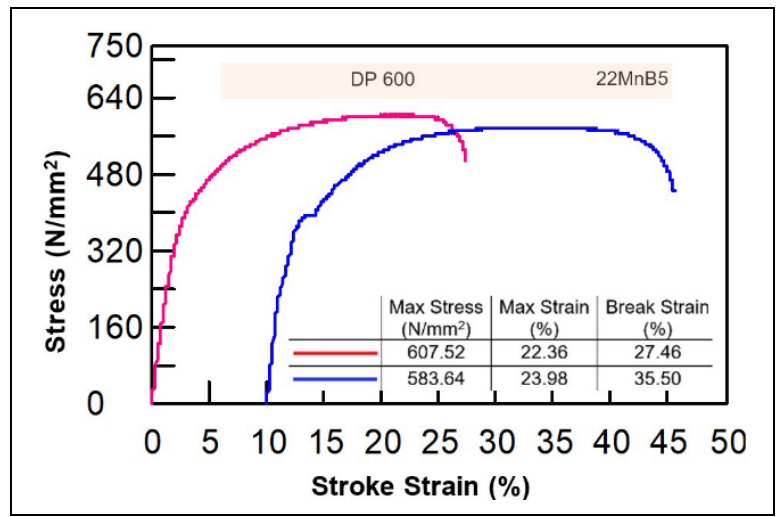

Figure 4. Base metals tensile strength results: As received $22 \mathrm{MnB5}$ and DP600.

\section{Welding method and experimental procedures}

RSW process was executed using an alternate current-ACpower source and medium frequency constant current oneMFDC. C construction RSW machine with $1000-\mathrm{Hz}$ medium frequency inverter (MFDC) from Serra Soldadura used for MFDC power source. AC and MFDC power source welding parameters are shown in Table 2.
The hardness tests were carried out to characterize weldment zones. The measurements were done with Shimadzu brand Vickers hardness tester with a 1000 g Vickers setting (HV1). Hardnesslines began with DP600 side base metal, progressed along the nugget and ended within the 22MnB5 base metal. According to drawings in Figure 5.

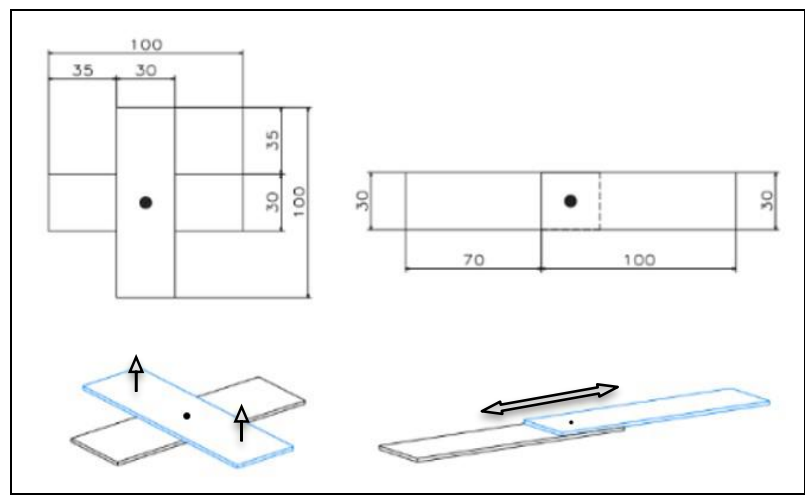

Figure 5. Specimen drawings of, TS and CT test for RSW. (unit=mm).

Tensile-shear (TS) and cross-tension (CT) destructive mechanical test samples done. Three samples were prepared separately for each TS and CT tests by MFDC and AC process. Test results showed that TS and CT values tolerance have been range between $\pm 2 \%$. One sample was prepared for hardness and microstructure analysis by MFDC and AC process separately. The hardness result values tolerance have been in the range of $\pm 5 \%$. Welded samples can be seen in Figure 6 .

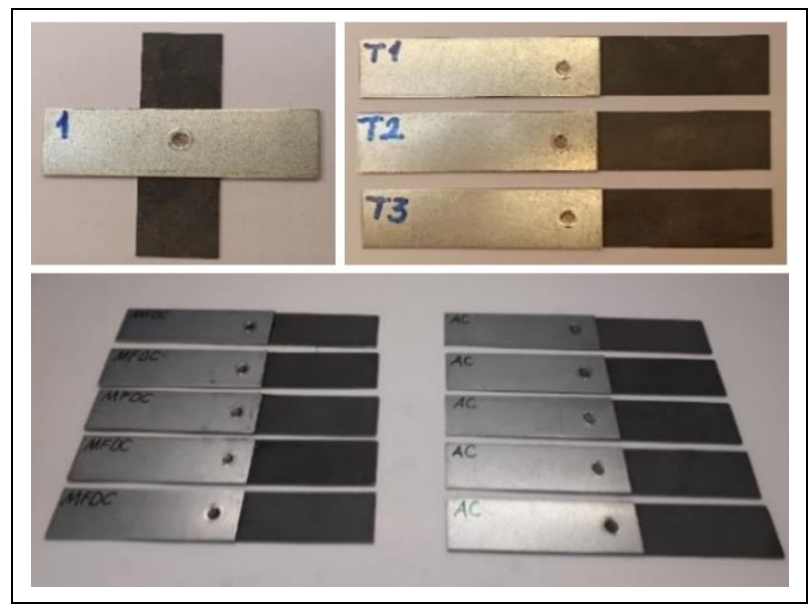

Figure 6. Welded specimens of micro-hardness, tensile-shear and cross-tension tests of RSW.

Table 2. AC and MFDC power source equipment welding parameters.

\begin{tabular}{cccccc}
\hline $\begin{array}{c}\text { Current } \\
\text { Type }\end{array}$ & $\begin{array}{c}\text { Welding time } \\
(\mathrm{ms})\end{array}$ & $\begin{array}{c}\text { Welding time } \\
(\text { cycle })\end{array}$ & $\begin{array}{c}\text { Welding current } \\
(\mathrm{kA})\end{array}$ & $\begin{array}{c}\text { Electrode Force } \\
(\mathrm{kN})\end{array}$ & $\begin{array}{c}\text { Electrode Diameter } \\
(\mathrm{mm})\end{array}$ \\
\hline AC & - & 23 & 7.21 & 410 & 6 \\
MFDC & 450 & - & 7.21 & 410 & 6 \\
\hline
\end{tabular}


Tensile-shear and cross-tension tests were executed at 5 $\mathrm{mm} / \mathrm{min}$. speed in SHIMADZU brand tensile testing device with a capacity of $50 \mathrm{kN}$. Before and after cross tension test process images can be seen in Figure7.

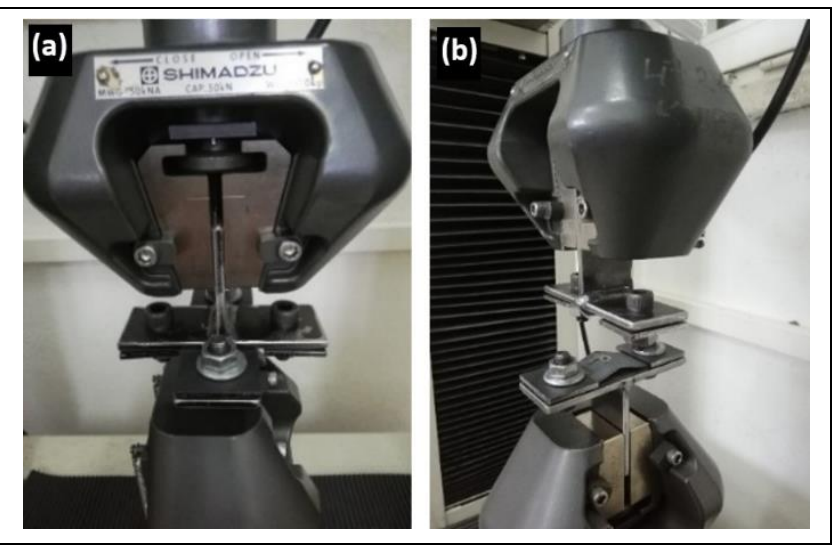

Figure 7. The cross-tension test images. (a): Before the test. (b): After the test.

\section{Result and discussions}

\subsection{Microstructural change in the weld and Hardness Profile}

Microstructure all around the welded area were illustrated in Figure 8. Although welding area on samples are roughly divided into three regions as the fusion zone (FZ), heat-affected zone (HAZ), unaffected base metal (BM), the HAZ can also be subdivided according to the thermal history. According to the cross-sectional optical micrographs of welded samples, at the DP600 and 22MnB5 side the base metal microstructure of the welded samples shows the same morphology after the material has been welded. No changes were observed in the microstructure of this region. As a result of epitaxial solidification, the fusion zone microstructure indicated columnar and martensitic (in needle form) structure growing from the nugget melting border to the nugget center. The reason for the fusion zone to result in a completely martensitic structure is the thermal history of the melting zone exceeds liquidus temperatures and then quickly quenched. While grain coarsening was observed near the fusion boundary on DP600 side, the microstructure in the HAZ on the 22MnB5 side is not clearly seen.

The high quality direct current obtained with MFDC technology gives more heat than $\mathrm{AC}$ for the same welding time. Therefore, microstructural analyzes have been carried out to see the effect of the same welding times on the weld metal microstructure.

When the fusion zone in Figure 8 are examined, it can be said that the reason for the relatively lower hardness values of the MFDC fusion zone is relatively coarse martensite grains with no obvious difference compared to the AC fusion zone

The increasing use of aluminum, titanium and its alloys, especially the new generation high strength steels, has led the development of medium frequency direct-current (MFDC) resistance spot welding technology. When the energy values per spot are examined, MFDC welding machines reduce the unit welding cost per spot by $\sim 30 \%$. Welding time is shorter due to DC current. With this technology, high power is obtained with the compact pulse form in the welding made at $1000 \mathrm{~Hz}$. For a certain welding time, MFDC technology provides more heat than conventional AC. Therefore, the MFDC method makes it more profitable than AC [26].

Alternating AC and MFDC weld current used in this study. AC current supply reasons the weld pool to grow in steps because of the current switches' polarity. DC welding current ensures continuous growth of the welding pool. The welding current is considered as the most effectual parameter to heat formation during RSW process.

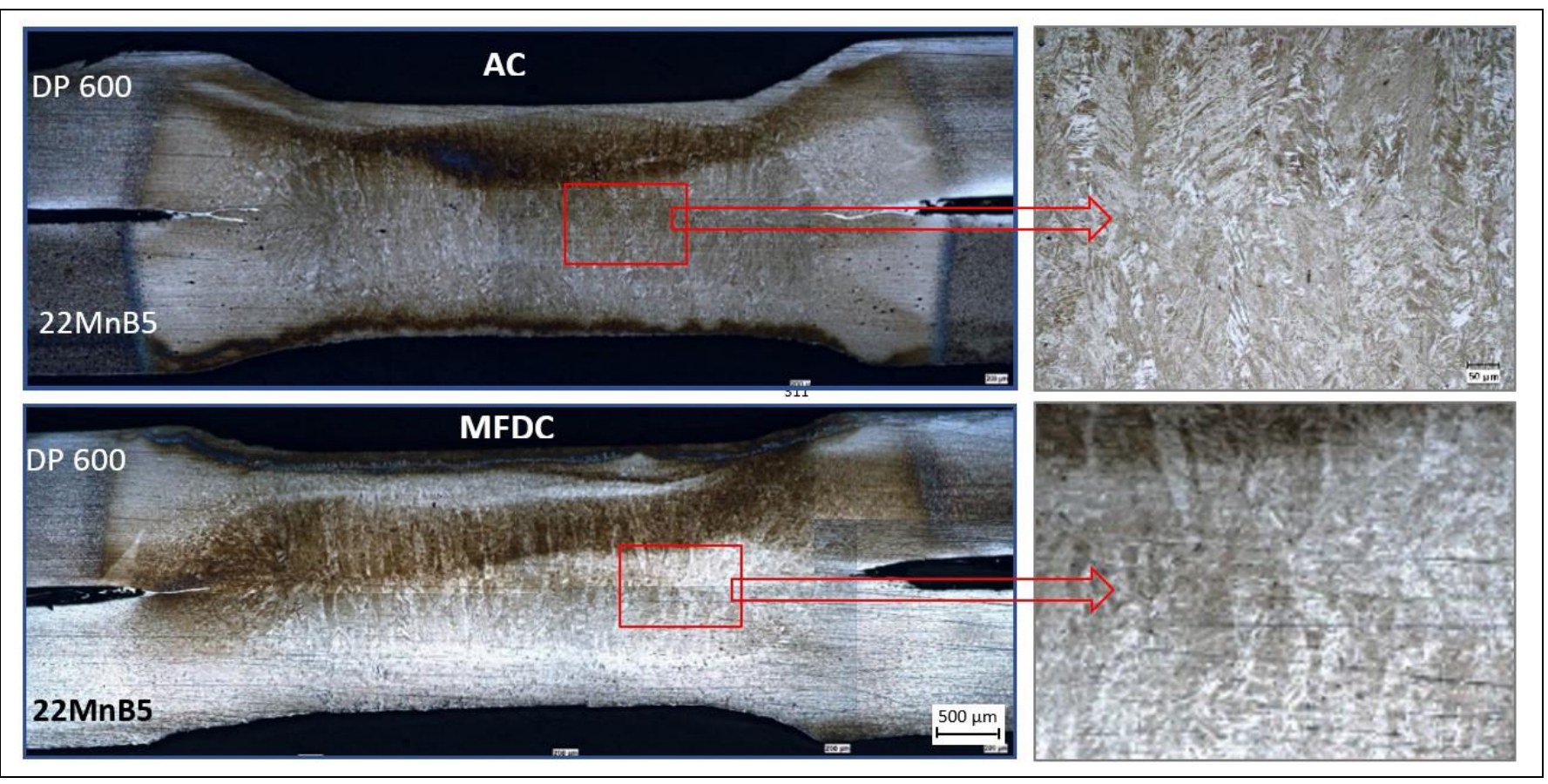

Figure 8. Cross-sectional optical micrographs of welded samples. 
For a given welding time, more heat is supplied to weldment area than conventional AC technology thanks to the MFDC welding. Because in this technology, high power is obtained due to the compact pulse form at a frequency of $1000 \mathrm{~Hz}$. While MFDC power source weld time is measured in millisecond, for $50 \mathrm{~Hz}$ AC power European machines, the time is measured in cycles (50 cycle/seconds). Increasing the heat input with MFDC technology reduces cooling speed due to shorter welding times than AC which is high current transformers. This is the reason why the hardness values in the fusion area in Figure 9 are low in the samples taken from the MFDC machine.

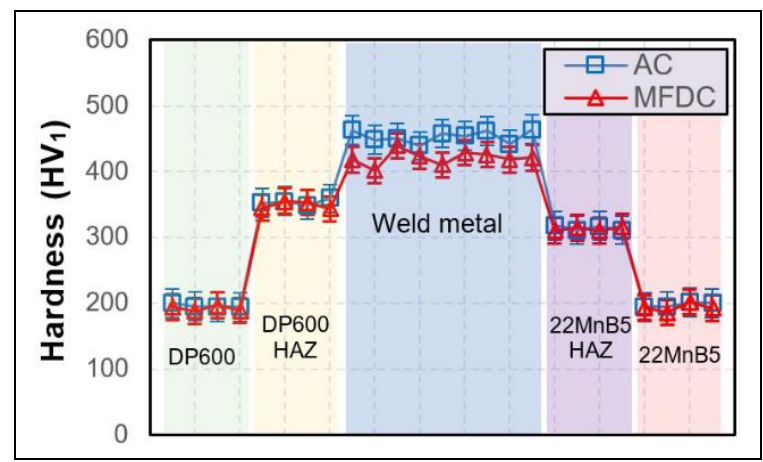

Figure 9. Microhardness profile of dissimilar welded Dp600 and as received $22 \mathrm{MnB5}$.

According this study supported by Ma et al [27] and Zhang, et al [28], in the hardness of weld nugget been more than two times higher than base metal due to the formation of lath martensite in the fusion zone. of plenty of martensite in the FZ explains the higher hardness of the FZ compared to the base metals. Hernandez et al [29], had reached similar conclusion too; The hardness of the nugget in dissimilar welds with DP600 paired to HSLA, DP780 and TRIP780 were about two times more than that of the base metal.

\subsection{Tensile-Shear and cross tension tests of the welded joints}

Dissimilar RSW of two common automotive BIW steel as received 22MnB5 with ferritic-pearlitic and DP600 with ferritic-martensitic structure was analyzed under CT and TS.

Figure 10. shows the strength capacity results of the spot welded samples according to different power sources. On cross tension test results graph can be seen in Figure 10. (a), max 5.1921 MPa force were obtained from MFDC power source samples, while $4.8143 \mathrm{MPa}$ were obtained from AC power source samples.

Figure 10 (a) is evaluated, MFDC power source samples tensile shear test result was measured max $12.637 \mathrm{MPa}$, while 11.512 $\mathrm{MPa}$ force was obtained from AC power source samples. A similar change in the elongation values of the tests was observed.

The failure modes obtained in TS and CT test for MFDC and AC process outputs are seen in Figure 11 and 12. Fracture failure mode can considerably effectiveness the ability to absorb energy and load carrying capacity in resistance spot welding. Generally, the pullout failure mode is the preferred fracture type due to its high plastic deformation and energy absorption ability [13],[22],[30].
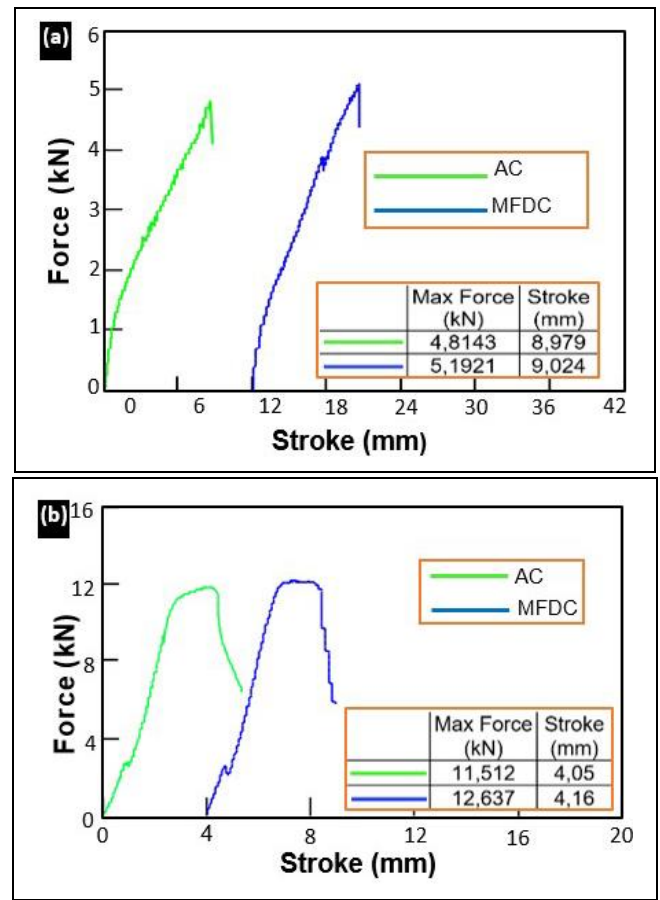

Figure 10. CT (a) and TS (b) test graphs to characterize spot weld strength from AC and MFDC technology.

The dominant fracture mechanism in the ST test is necking across the thickness. [30]-[34]. Therefore, in this test, the location of the fracture for pull out failure mode is managed by the hardness profile characteristic of the weld. The necking tendency to was formed at the lowest value of hardness. In RSW welding of low carbon steels, it has been found experimentally that necking starts from basic metal. [31],[35]. Similar observations have been observed in the RSW welds of HSLA (High Strength Low Alloy) and DP600 steels. [24],[25]. This can be connected with the weak hardness of the base metal compared to the HAZ and the weld metal. Failure modes were inspected visual with naked eyes, a similar result was observed for tensile shear sample. Pull-out failure mode fracture image of MFDC process output can observed in Figure11. Partial interface failure mode was encountered at AC process tensile shear output samples as shown in Figure 11.

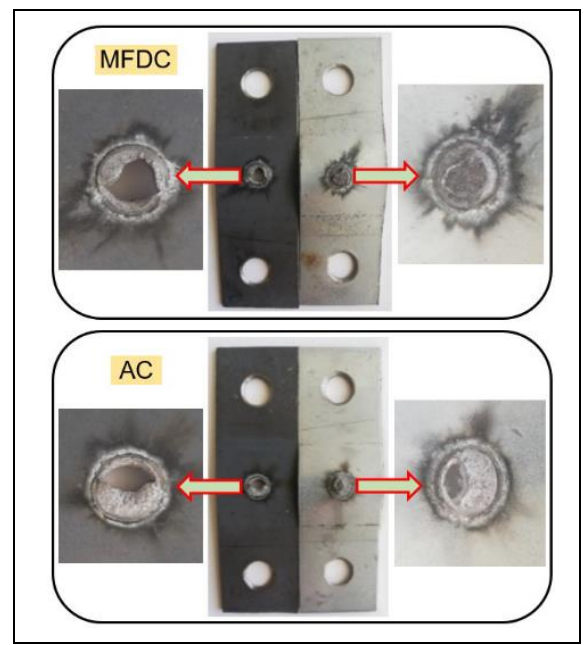

Figure 11. The failure modes encountered after TS tests. 
As can be seen in Figure 12, after MFDC and AC process output samples' cross tension tests, partial interface failure modes were encountered. According to reviews of cross tension failure modes with naked eye at MFDC and AC process output samples' interfacial fracture ratio were observed $60 \%$ and $25 \%$ respectively.

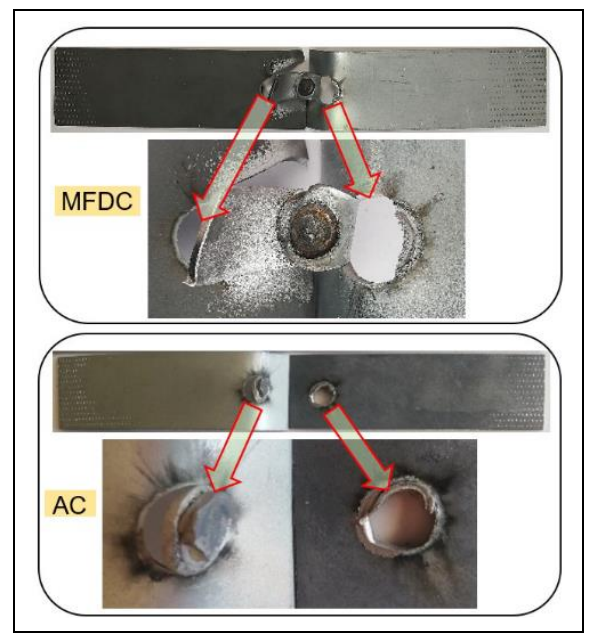

Figure12. The failure modes encountered after CT tests.

After destructive tests, the reasons affecting two important characteristics of the fracture should be examined. these are failure mode and failure load. It can be said AC or DC power source equipment influence the fracture (failure mode) with.

\section{Conclusions}

A comparative work has been carried out to analyze the mechanical properties between the AC and MFDC resistance spot welded advised high strength steels. At the same time this paper presents the mechanical and failure behavior, of resistance spot welded joints between as-delivered 22MnB5 and double phase DP600 steels.

As seen below, the conclusions are deduced and listed from this study:

- The hardness values in the fusion area were measured low on the samples taken from the MFDC current source. The reason of these hardness results was been increase the heat input by MFDC current source and reduce cooling speed due to shorter welding times than AC,

- TS and CT tests were performed in order to assessment the effect of AC and MFDC waves on strength values. The results show that the power source of MFDC showed relatively higher performance (approximately 10\%) for tensile-shear and (more than 5\%) for cross tension test compared to $\mathrm{AC}$,

- After cross tension tests partial interface failure occurred MFDC and AC process output samples. The interfacial fracture ratio were observed $60 \%$ and $25 \%$ respectively for MFDC and AC,

- While partial interface failure mode was observed at AC process output samples after tensile shear tests, Pull-out failure mode was observed at MFDC process output samples.
The main conclusion of the evaluated study: MFDC technology has shown positive influence on mechanical properties and has improved the strength capability of resistance spot welded join.

Research suggestion: In this work as-delivered 22MnB5 and DP600 steel sheets used. However, Body in White antiintrusion steel components are being increasingly produced by hot stamped 22MnB5 and its upper grades. The next work with hot stamped UHSS might be useful for the automotive BIW industry.

\section{Acknowledgments}

The authors acknowledge the support of Karabük Üniversitesi BAP (Project No: FDK-2019-2095) for funding this work.

\section{Author contribution statements}

In the scope of this study, the Mehtap HIDIROGLU in the formation of the idea, the literature review, supplying the materials and the design the parameters; Unal KAHRAMAN desinging the parameters with Mehtap HIDIROGLU and optaining samples with MFDC/AC technology; the Nizamettin KAHRAMAN formation of idea, assessment of obtained results, and checking the article in terms of content were contributed.

\section{Ethics committee approval and conflict of interest statement}

"There is no need to obtain permission from the ethics committee for the article prepared".

"There is no conflict of interest with any person / institution in the article prepared".

\section{References}

[1] Fan DW, Kim HS, Birosca S, De Cooman BC. “Critical Review of Hot Stamping Technology for Automotive Steels". Materials Science and Technology Conference, Detroit, Michigan, USA, 16-20 September 2007.

[2] Karbasian H, Tekkaya AE. "A review on hot stamping". Journal of Materials Processing Technology, 210(15), 2103-2118, 2010.

[3] Gui Z, Liang ZY. "Formability of aluminum-silicon coated boron steel in hot stamping process". Transactions of Nonferrous Metals Society of China, 24(6), 1750-1757, 2014.

[4] Neugebauer R, Schieck F, Polster SA, Mosel A. Rautenstrauch A. Schönberr J, Pierschel N. "Presshardening-An innovative and challenging technology". Archives of Civil and Mechanical Engineering, 12(2), 113-118, 2012.

[5] Tungtrongpairoj J, Uthaisangsuk V, Bleck W. "Determination of yield behaviour of boron alloy steel at high temperature". Journal of Metals, Materials and Minerals, 19(1), 29-38, 2009.

[6] Liang W, Liu Y, Zhu B, Zhou M, Zhang Y. “Conduction heating of boron alloyed steel in application for hot stamping". International Journal of Precision Engineering and Manufacturing, 16(9), 1983-1992, 2015.

[7] Jiang C, Shan Z, Zhuang B, Zhang M, Xu Y. "Hot stamping die design for vehicle door beams using ultra-high strength steel". International Journal of Precision Engineering and Manufacturing, 13(7), 1101-1106, 2012.

[8] Altan T, Tekkaya AE. Sheet Metal Forming-Processes and Applications, Chapter 7: Hot Stamping. Ohio, USA, ASM International publishing, 2012. 
[9] Kondratiuk J, Kuhn P, Labrenz E, Bischoff C. "Zinc coatings for hot sheet metal forming: Comparison of phase evolution and microstructure during heat treatment". Surface \& Coatings Technology, 205(17), 4141-4153, 2011.

[10] Windmann M, Röttger A, Theisen W. "Formation of intermetallic phases in Al-coated hot-stamped 22MnB5 sheets in terms of coating thickness and $\mathrm{Si}$ content". Surface \& Coatings Technology, 246, 17-25, 2014.

[11] Abbasi M, Ketabchi M, Ramazani A, Abbasi M, Prahl U. "Investigation into the effects of weld zone and geometric discontinuity on the formability reduction of tailor welded blanks". Computational Materials Science, 59, 158-164, 2012.

[12] Ramazani A, Mukherjee K, Prahl U, Bleck W. "Transformation-induced, geometrically necessary, dislocation-based flow curve modeling of dual-phase steels: effect of grain size". Metallurgical and Materials Transactions A, 43, 3850-3869, 2012.

[13] Sun X, Stephens EV, Khaleel MA. "Effects of fusion zone size and failure mode on peak load and energy absorption of advanced high strength steel spot welds under lap shear loading conditions". Engineering Failure Analysis, 15(4), 356-367, 2008.

[14] W Hou. "Methods and Systems for Resistance Spot Welding using Direct Current Micro Pulses". United States of America Patent Patent Pending, Pub No. US 2001/0036816 A1, 17 February 2011.

[15] Park SS, Choi YM, Nam DG, Kim YS, Yu J, Park YD. "Evaluation of resistance spot weld interfacial fractures in tensile-shear tests of TRIP1180 steels". The Korean Welding and Joining Society, 26(6), 625-635, 2008.

[16] Lee HW, Kim YH, Lee SH, Lee SK, Lee KH, Park JU, Sung JH. "Effect of boron contents on weldability in high strength steel". Journal of Mechanical Science and Technology, 21, 771-777, 2007.

[17] Shao J, Hou C. Resistance Spot Welding and In-Process Heat Treatment of Hot Stamped Boron Steel. University of Waterloo, Mechanical Engineering Master Thesis, Waterloo, Ontario, Canada, 2016.

[18] Choi HS, Park GH, Lim WS, Kim B. "Evaluation of weldability for resistance spot welded single-lap joint between GA780DP and hot-stamped 22MnB5 steel sheet". Journal of Mechanical Science and Technology, 25(6), 1543-1550, 2011.

[19] Aras S, Ertan R, Özgül, G, Hande. "Investigation of mechanical properties of high strength steel welded by resistance spot welding". Pamukkale University Journal of Engineering Sciences, 24(1), 63-68, 2018.

[20] Tunçel O, Aydın H. "Tensile properties of resistance spot welded ultra high strength steel usibor 1500". IESS 2019 International Engineering and Science Symposium, Siirt, Turkey, 20-22 June 2019.

[21] Sejč P, Belanová J. "The effect of welding parameters on the properties of join between studs and steel sheet USIBOR Type 22MnB5". Manufacturing Technology, 19(3), 492-498, 2019.

[22] Sun X, Stephens EV, Khaleel MA. "Effects of fusion zone size and failure mode on peak load and energy absorption of advanced high-strength steel spot welds". Welding Journal, 86(1), 18-25, 2007.
[23] Khan MI, Kuntz ML, Zhou Y. "Effects of weld microstructure on static and impact performance of resistance spot welded joints in advanced high strength steels". Science and Technology of Welding and Joining, 13(3), 294-304, 2008.

[24] Marya M, Gayden XQ. "Development of requirements for resistance spot welding dual-phase (DP600) steels part 2: statistical analyses and process maps". Welding Journal, 84(12), 197-204, 2005.

[25] Oikawa H, Murayama G, Sakiyama T, Takahashi Y, Ishikawa T. "Resistance spot weldability of high strength steel (HSS) sheets for automobile". Nippon Steel Technical Report, 395(385), 39-45, 2006.

[26] Kahraman N, Gülenç B. Modern Welding Technology. Ankara, Turkey, Epa-Mat publishing, 2020.

[27] Ma C, Chena DL, Bhole SD, Boudreau G, Lee A, Biro E. "Microstructure and fracture characteristics of spotwelded DP600 steel". Materials Science and Engineering A 485, 334-346, 2008.

[28] Zhang H, Wei A, Qiu X, Chen J. "Microstructure and mechanical properties of resistance spot welded dissimilar thickness DP780/DP600 dual-phase steel joints". Materials and Design 54, 443-449, 2007.

[29] Hernandez B, V. H Kuntz, M. L, Khan, M. I, Zhou Y, "Influence of microstructure and weld size on the mechanical behaviour of dissimilar AHSS resistance spot welds". Science and Technology of Welding and Joining 13(8), 169-776, 2008.

[30] Pouranvari M, Marashi SPH. and Safanama DS. "Failure mode transition in AHSS resistance spot welds. Part II: experimental investigation and model validation". Materials Science and Engineering $A$, 528(29-30), 8344-8352, 2011.

[31] Pouranvari M, Abedi A, Marashi P, Goodarzi M. "Effect of expulsion on peak load and energy absorption of low carbon steel resistance spot welds". Science and Technology of Welding and Joining, 13(1), 39-43, 2008.

[32] Lin PC, Lin SH, Pan J. "Modeling of failure near spot welds in lap-shear specimens based on a plane stress rigid inclusion analysis". Engineering Fracture Mechanics, 73(15), 2229-2249, 2006.

[33] Goodarzi M, Marashi SPH, Pouranvari M. "Dependence of overload performance on weld attributes for resistance spot welded galvanized low carbon steel". Journal of Materials Processing Technology, 209(9), 4379-4384, 2009.

[34] Dancette S, Massardier V, Merlin J, Fabregue D, Dupuy T. "Investigations on the mechanical behavior of advanced high strength steels resistance spot welds in cross tension and tensile shear". Advanced Materials Research, 89-91, 130-135, 2010.

[35] Chao YJ. "Failure mode of spot welds: interfacial versus pullout". Science and Technology of Welding and Joining, 8(2), 133-137, 2003. 